\title{
Rusztowania budowlane - przepisy a praktyka
}

\author{
Michał Pieńko, Aleksander Robak, Ewa Błazik-Borowa \\ Katedra Mechaniki Budowli, Wydziat Budownictwa i Architektury, Politechnika Lubelska, \\ e-mail:m.pienko@pollub.pl,a.robak@pollub.pl,e.blazik@pollub.pl
}

Streszczenie: W artykule opisano problematykę związaną z rusztowaniami budowlanymi. Ze względu na traktowanie rusztowań jako konstrukcje podrzędne o małym znaczeniu często dochodzi do zaniedbań w jakości ich wykonania. Akty prawne, dotyczące rusztowań, nie zawsze są jednoznaczne, co rodzi wiele problemów. Pozornie niewielkie zmiany w schemacie statycznym, wynikające z konieczności dostosowania rusztowania do nieregularnych kształtów obiektu, mogą znacząco zmniejszyć nośność konstrukcji rusztowania. Każdy z obiektów budowlanych wymaga indywidualnego podejścia zarówno projektantów rusztowań jak i montażystów. Ponieważ rusztowania wykorzystywane jako tymczasowe zadaszenia i przekrycia umożliwiające przeprowadzenie prac wykończeniowych w czasie zimy nie są ujęte w katalogach każdorazowo konieczne jest opracowanie oddzielnej dokumentacji. Rusztowania są ustawiane w bezpośrednim sąsiedztwie istniejących lub wznoszonych obiektów i wymagają uwzględnienia infrastruktury wokół nich. Konieczne jest również prześledzenie procesu technologicznego w celu wyeliminowania możliwych kolizji rusztowania z innymi pracami wykonywanymi w obrębie obiektu.

Słowa kluczowe: rusztowanie, akty prawne, przepisy BHP, bezpieczeństwo.

\section{Wstęp}

Zadaniem rusztowań budowlanych jest zapewnienie bezpieczeństwa podczas wykonywania prac na wysokości. Ze względu na tymczasowość rusztowań, konstrukcje te są traktowane jako drugorzędne i nie przywiązuje się do nich szczególnej uwagi. Takie podejście powoduje, że konstrukcja rusztowania zamiast zapewniać bezpieczeństwo jest źródłem poważnych awarii, których skutkiem są obrażenia ciała a nawet śmierć użytkowników. Błędy występują niestety $\mathrm{w}$ każdym etapie związanym $\mathrm{z}$ funkcjonowaniem rusztowania, czyli zarówno podczas projektowania, wznoszenia, jak i użytkowania. Zadaniem aktów prawnych między innymi takich, jak $[1,2,3,4]$, jest wyeliminowanie błędów i stworzenie wytycznych ograniczających prawdopodobieństwo wystąpienia awarii. Sam przepis i powołanie się na niego nie zapewni bezpieczeństwa konstrukcji. Konieczne jest wprowadzenie zapisu aktu prawnego w życie i postępowanie zgodnie z nim. Każdy wznoszony obiekt wymaga indywidualnego podejścia do problemu rusztowań a dodatkowo nie zawsze mamy sytuacje jednoznacznie opisane w aktach prawnych. W takim przypadku konieczne jest zdroworozsądkowe podejście osób, odpowiadających za organizację pracy budowy, w tym rusztowanie, którymi są uczestnicy procesu inwestycyjnego, czyli inspektor nadzoru inwestorskiego i kierownik budowy [5].

W artykule zostaną przedstawione problemy funkcjonowania rusztowania, związane $\mathrm{z}$ użytkowaniem rusztowania $\mathrm{w}$ rzeczywistych warunkach zastanych na terenie budowy. Przy okazji zostanie też pokazany problem zakresu poszczególnych dokumentów, określających zakres funkcjonowania rusztowania. Zasady bezpieczeństwa pracy są przede wszystkim określone w rozporządzeniach (np. [1,2,3,4]. Normy i projekt określają kształt 
obiektu, ale też zawierają zapisy dotyczące zasad BHP. Bardzo szczegółowe zapisy, związane z bezpieczeństwem, zawierała obecnie już nieobowiązująca, norma 6 . Teraz decyzje o wielu aspektach funkcjonowania rusztowania pozostawia się projektantom. Nie wszystkie sytuacje da się przewidzieć i zapisać w przepisach prawnych. Problem dotycz zarówno obiektów nowo wznoszonych jak i istniejących. Coraz śmielsze konstrukcje wymagają dokładnego prześledzenia technologii ich wznoszenia i uwzględnienia konieczności zastosowania rusztowań. Obiekty istniejące a w szczególności obiekty zabytkowe posiadają ubogą dokumentację i bardzo często niespójna z rzeczywista sytuacją na terenie budowy.

\section{Ustawienie rusztowania na podłożu}

Problem właściwego wykonania rusztowania zapewniającego bezpieczne użytkowanie pojawia się na samym początku jego montażu. Jednym z najważniejszych elementów właściwie zmontowanego rusztowania jest jego ustawienie na podłożu. Zgodnie z Rozporządzeniem [1] rusztowanie należy ustawić na podłożu ustabilizowanym i wyprofilowanym, ze spadkiem umożliwiającym odpływ wód opadowych. Więcej informacji na temat posadowienia można znaleźć w normie [6]. W tej normie [6] znajdują się informacje, dotyczące usytuowania podkładów, doboru ich wymiarów i sposobu wykonywania tarasów w obrębie terenów pochylonych. Norma [6] jednoznacznie zabrania stosowania podkładów klinowych, popękanych lub $\mathrm{w}$ postaci cegieł. $\mathrm{W}$ tej normie zostały przedstawione też warunki, jakie musi spełniać podłoże gruntowe. Wymagana minimalna nośność podłoża według przytoczonej normy wynosi $10 \mathrm{MPa}$, co jest ewidentnym błędem. Jest to zbyt wysoka wartość a zastosowanie się do tego zapisu oznacza, że rusztowanie powinno zostać ustawione na płytach betonowych lub podłożu kamiennym. Można się domyślać, że wartość ta dotyczy wytrzymałości podkładów a nie nośności podłoża. Natomiast informacja o tym, jaka powinna być nośność podłoża, na którym ustawiane jest rusztowanie, powinna znaleźć się w dokumentacji rusztowania ( $\mathrm{w}$ instrukcji montażu lub projekcie indywidualnym rusztowania). Najczęściej jest wartość około $100 \mathrm{kPa}$. W celu określenia nośności gruntu konieczne jest wykonanie badań na przykład za pośrednictwem płyty VSS. Niestety często badania ograniczają się jedynie do wizji lokalnej montera i sprawdzeniu czy grunt nie ulega osiadaniu pod wpływem ciężaru człowieka. Jednak większym problemem niż brak badań podłoża jest ustawianie rusztowań za pośrednictwem cegieł lub pustaków ustawionych jeden na drugim (Rys. 1).

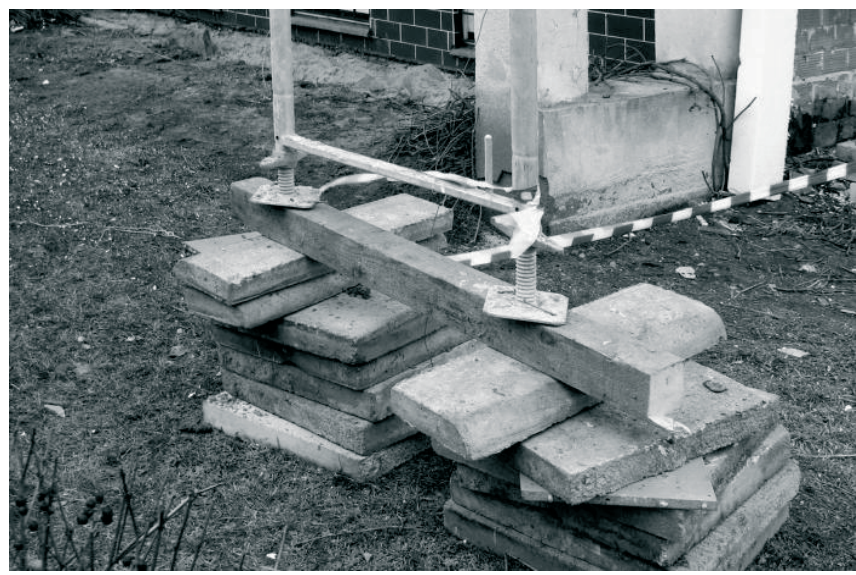

Rys. 1. Błędnie wykonane posadowienia rusztowania (Fot. Peri Polska) 
W wielu publikacjach możemy znaleźć liczne przykłady niewłaściwego posadowienia rusztowań [7]. Najczęściej wynika to z niedbałości wykonawcy lub braku elementów umożliwiających regulowanie różnic poziomów w obrębie budynku. Rusztowania są lekkimi konstrukcjami stalowymi szczególnie wrażliwymi na osiadanie punktów podparcia. Utrata podpory może doprowadzić na znacznego wzrostu naprężeń w obrębie konstrukcji lub zmiany konstrukcji w mechanizm. Sytuacja przedstawiona na rysunku nr 1 jest niebezpieczna za równo ze względu na możliwość rozsunięcia się poszczególnych elementów, na których zostało ustawione rusztowanie, jak również ze względu na przekazanie obciążeń na podłoże za pośrednictwem dwóch niezależnych podkładów w postaci płyt chodnikowych. Przepisy jednoznacznie wskazują, iż rusztowanie należy ustawiać na pojedynczym podkładzie, na którym znajdują się obie podstawki.

\section{Kotwienie}

Niezwykle istotnym elementem rusztowania jest jego właściwe zakotwienie. Katalogi producentów jednoznacznie określają sposób kotwienia konstrukcji rusztowania do istniejącego obiektu. Zadaniem projektanta, w przypadku konstrukcji nietypowych, jest rozmieszczenie kotwień zapewniających stateczność oraz przeniesienie obciążenia wynikającego z obciążenia wiatrem [8]. Układ kotwienia, niezgodny z zaleceniami instrukcji montażu, jest najczęstszym powodem uznania konstrukcji rusztowania jako konstrukcji nietypowej, wymagającej wykonania projektu indywidualnego. W większości nowych obiektów elewacja jest wykonana w postaci szklanych lub kamiennych segmentów szczelnie wypełniających elewację. Wymusza to zastosowanie minimalnej liczby kotwień, gdyż każde kotwienie eliminuje dany obszar z montażu. Ograniczając liczbę kotwień w celu zwiększenia frontu robót należy stosować się do szczegółowych wytycznych projektanta co do formy układu kotwienia oraz rodzaju kotew (pojedyncza kotwa, podwójna, wklejana, itp.). Projektant jednoznacznie określa czy kotwienie ma postać kotew krótkich, przenoszących głównie obciążenie prostopadłe do elewacji, czy kotew długich lub trójkątnych przenoszących zarówno obciążenia prostopadłe, jak i równoległe poziome do fasady.

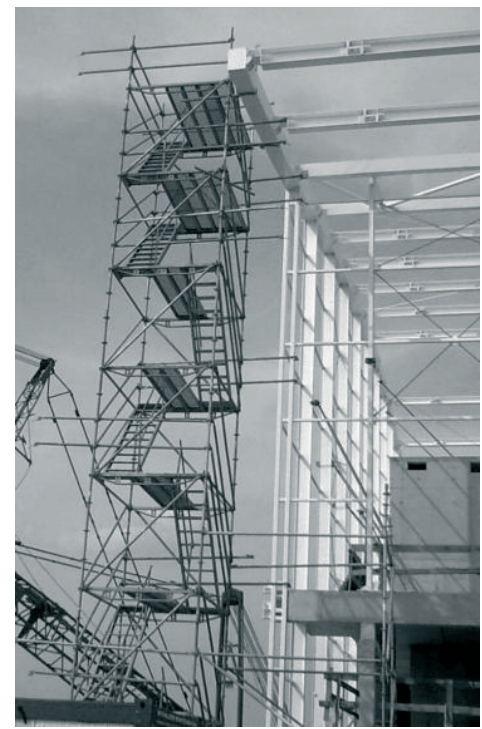

Rys. 2. Kotwienie w postaci obejm wykonanych z rur uniwersalnych (Fot. Altrad Mostostal) 
Szczególnie niebezpieczną sytuacją jest ograniczanie liczby kotwień w przypadku stosowania zakryć ochronnych w postaci siatek lub plandek. W znacznym stopniu zwiększa to wartości sił występujących w kotwieniach. Każda z siatek ochronnych posiada określoną przepuszczalność potwierdzoną certyfikatem, dzięki czemu obciążenia wiatrem może być zmniejszone. W przypadku plandek, szczególnie stosowanych w okresie zimowy w celu zapewnienia pełnego zakrycia obszaru roboczego i jego ogrzania, obciążenie wiatrem należy uwzględnić w pełnym zakresie. Wymusza to często zastosowanie kotwień chemicznych o większej nośności, niestety jest to rozwiązanie dużo droższe. Problemy z kotwieniem pojawiają się również w przypadku obiektów wykonanych w technologii prefabrykacji. Ze względu na sprężenie elementów konstrukcji konieczne jest rozmieszczenie kotwienia zgodnie ze wskazanymi możliwymi obszarami wierceń. Alternatywnym rozwiązanie klasycznego kotwienia może być zastosowanie obejmy w postaci rur uniwersalnych wokół elementów nośnych (Rys. 2). Takie rozwiązanie jest często stosowane w przypadku remontów obiektów przemysłowych [9]. Obejma, wykonana z rur, stanowi podporę blokująca przesuw w kierunku poziomym zarówno na odrywanie od konstrukcji, jak również parcie w kierunku konstrukcji. Pracochłonnym i wymagającym znacznej liczby elementów jest rozwiązanie polegające na rozbudowie konstrukcji rusztowania w kierunku prostopadłym do elewacji i zastosowanie dociążenia lub odciągów. Rozwiązanie to jest rzadko spotykane, ponieważ zajmuje znaczne obszary i może kolidować z innymi pracami wykonywanymi wokół obiektu.

\section{Zabezpieczenia BHP}

Podczas wykonywanie robót budowanych należy bezwzględnie zachowywać środki bezpieczeństwa i higieny pracy. Budownictwo ze względu na specyfikę pracy jest jedną z dziedzin gospodarki, w której najczęściej dochodzi do wypadków z udziałem ludzi. Szczególnie niebezpieczne są prace wykonywane na wysokościach. Nieodzownym elementem przeprowadzania prac są rusztowania budowlane, często bagatelizowane zarówno przez pracowników jak i kierowników budów. Najczęściej do wypadków dochodzi na niewielkich rusztowaniach często niebędących pod jakikolwiek nadzorem.

\subsection{Teren budowy}

Teren budowy niestety nie zawsze jest to teren ogrodzony i zabezpieczony przed dostępem osób trzecich. Wiele prac budowlanych z wykorzystaniem rusztowań jest prowadzonych bezpośrednio przy ulicach i na osiedlach. Zgodnie z Rozporządzeniem [1] teren, na którym wykonywane są roboty bezpośrednio związane z montażem lub demontażem rusztowań, należy oddzielić za pomocą ogrodzenia w odległości 1/10 wysokości rusztowania, jednak nie mniej niż $6 \mathrm{~m}$. Jeżeli rusztowanie jest wznoszone na terenie o zwartej zabudowie praktycznie uniemożliwia to wykonywanie jakichkolwiek prac w obrębie rusztowania. Dlatego to rozporządzenie dopuszcza inne rozwiązania techniczne. W przypadku rusztowań takim rozwiązaniem jest założenie siatki ochronnej z zastrzeżeniem, że siatka ochronna nie zwalnia z obowiązku stosowania balustrad. Ważnym elementem, zabezpieczającym przed spadającymi narzędziami, są daszki ochronne. Zgodnie z Rozporządzeniem [1] należy je montować w rusztowaniach, usytuowanych bezpośrednio przy drogach i ulicach oraz miejscach przejazdów i przejść dla pieszych. Daszki ochronne powinny znajdować się na wysokości nie mniejszej niż $2,4 \mathrm{~m}$ nad terenem w najniższym miejscu i być nachylone pod kątem $45^{\circ} \mathrm{w}$ kierunku źródła zagrożenia. Szerokość daszka ochronnego powinna wynosi co najmniej o 1,0 m więcej niż szerokość przejścia lub przejazdu. W nieobowiązującej normie [6] znajdowały się także zapisy, dotyczące minimalnych wysięgów 
daszków ochronnych, które według zapisów normowych powinny wynosić 2,20 m dla rusztowań o wysokości do $20 \mathrm{~m}$ oraz 3,50 m dla rusztowań powyżej $20 \mathrm{~m}$ wysokości. Obecnie ten zapis nie obowiązuje, bo w każdym przypadku, gdy nie można wygrodzić odpowiednio dużej strefy niebezpiecznej, należy na rusztowaniu założyć siatkę ochronną. Rusztowania zarówno na terenie budowy jak i rusztowania usytuowane przy drogach i ulicach są narażone na uderzenia pojazdów mechanicznych, dlatego stojaki rusztowania usytuowane przy bramach, prześwitach i przejazdach powinny być zabezpieczone odbojami nie związanymi z konstrukcją (Rys. 3).

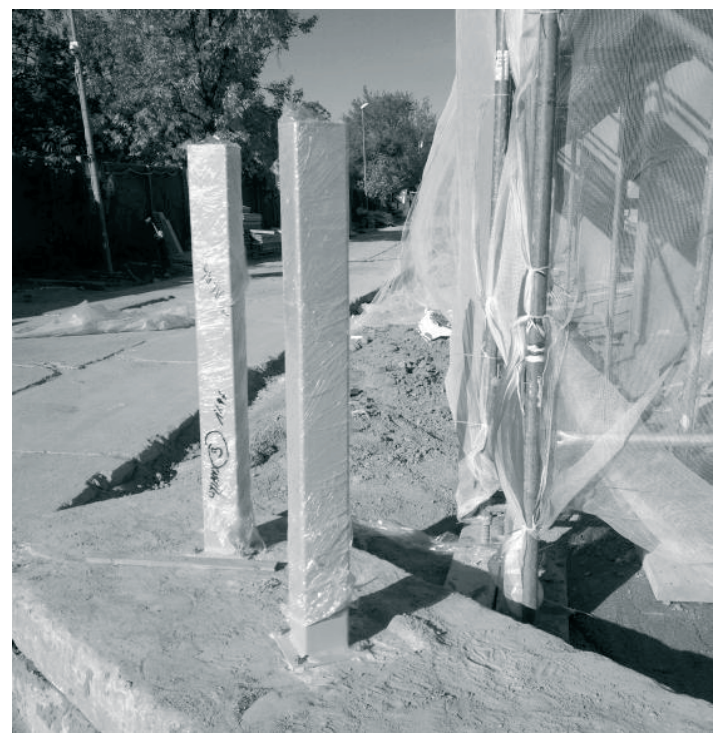

Rys. 3. Odbojnice słupowe w narożu rusztowania w sąsiedztwie drogi tymczasowej (Fot. Opeus)

Nie ma jednak żadnego zapisu określającego, w jakiej odległości od rusztowania można zamontować wspomniane odboje i jakie warunki one powinny spełniać. Ponieważ na budowie porusza się ciężki sprzęt, najlepszym rozwiązanie jest umieszczenie odbojnic możliwie jak najdalej od rusztowania $\mathrm{z}$ jednoczesnym uwzględnieniem rozmiarów terenu budowy. Ze względu na coraz bardzie zwartą formę zabudowy nie ma miejsca na stosowanie odbojnic znacznie oddalonych od rusztowania. Odbojnice powinie w skuteczny sposób ochronić rusztowanie przed możliwością uderzenia jakichkolwiek pojazdów mechanicznych pracujących na terenie budowy lub zminimalizować skutki uderzenia.

Jednak do awarii z udziałem pojazdów najczęściej dochodzi w trakcie wykonywania wiaduktów, w których rusztowania są wykorzystywane jako konstrukcja wsporcza [10]. Pomimo zachowania wymaganej skrajni i stosowania odbojnic dochodzi do uszkodzenia konstrukcji wsporczych (np. [11]). Pociąga to za sobą ogromne koszty związane ze zmianą konstrukcji wsporczej a czasami koniecznością usunięcia już częściowo wykonanego przęsła wiaduktu.

\subsection{Zabezpieczenia pomostów roboczych}

Każdy pomost roboczy powinien posiadać barierki ochronne na wysokości 0,5 m oraz 1,0 m powyżej poziomu pomostu. W większości przypadków rusztowań oporęczowanie jest montowane i nie ma co do niego zastrzeżeń. Dużo gorzej wygląda sytuacja z krawężnikami zabezpieczającymi, które zabezpieczają przed upadkiem narzędzi z poziomu pomostu, 
oraz poręczami czołowymi. Przytoczone elementy często są pomijane, a należy pamiętać, że nie da się zapewnić bezpieczeństwa tylko częściowo. Ważną kwestią jest również pomost zabezpieczający, którego zadaniem jest zatrzymanie upadku pracownika na poziomie poniżej poziomu pracy. W typowych rusztowaniach, takim pomostem jest pomost, znajdujący się poniżej pomostu roboczego. Kwestia pomostu zabezpieczającego staje się problematyczna w przypadku platform roboczych. Zastosowanie pomostu zabezpieczającego na całej powierzchni pod pomostem roboczym praktycznie dwukrotnie zwiększa koszty wynajmu i montażu platformy. $Z$ tego powodu często pomost zabezpieczający jest zastępowany siatkami bezpieczeństwa, montowanymi bezpośrednio pod pomostem roboczym. Jest to również rozwiązanie kosztowne, dlatego też często w opracowaniach technicznych określających zasady użytkowania platform roboczych możemy odnaleźć zapis, iż osoby przebywające na platformie roboczej należy wyposażyć w środki ochrony indywidualnej w postaci szelek bezpieczeństwa. Stosowanie szelek bezpieczeństwa umożliwia użytkowanie rusztowania bez pomostu zabezpieczającego. Należy jedna wziąć pod uwagę, że w znacznym stopniu utrudnia to swobodę wykonywania prac. Osoba przebywająca na platformie bez pomostu zabezpieczającego powinna być przypięta do elementu zapewniającego przeniesienie jego ciężaru w razie upadku. Miejsce przypięcia uprzęży nie może być przypadkowe. Niestety najczęściej możemy obserwować niestaranne przypięcie w obrębie samego rusztowania w miejscach, które nie zapewnią przeniesienia obciążenia związanego z upadkiem pracownika.

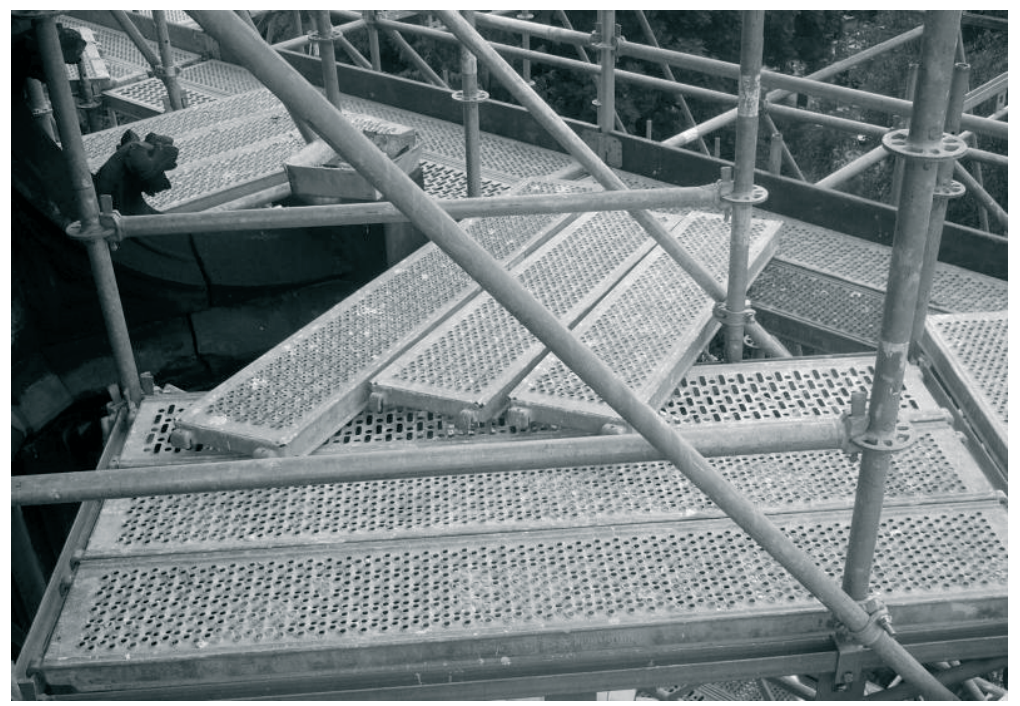

Rys. 4. Przykład uzupełnienia powierzchni pomostu roboczego przerzutami

Kolejnym „grzechem” użytkowników i montażystów rusztowań jest pozostawianie obszarów bez wypełnienia pomostami. Ma to miejsce szczególnie w przypadku obiektów o nieregularnym kształcie, które wymagają uzupełniania powierzchni pomostów przerzutami (Rys. 4). Elementy pomostowe powinny być tak układane, aby długość zakładu z każdej strony przerzutu wynosiła co najmniej $20 \mathrm{~cm}$. Przerzut powinien być zabezpieczony przed możliwością przesunięcia np. za pomocą drutów stalowych lub gwoździ. Najbardziej problematycznym przepisem, dotyczącym zabezpieczeń pomostów, jest konieczność stosowania poręczy i krawężników od strony wewnętrznej w przypadku odległości pomostu rusztowania od ściany powyżej $20 \mathrm{~cm}$. Praktycznie w przypadku każdej konstrukcji 
rusztowania służącej do montażu elementów elewacji odległość od ściany przewyższa wartość $20 \mathrm{~cm}$. Producenci rusztowań widząc potrzeby rynku zaczęli produkować ramki rusztowaniowe z kasetami, umożliwiającymi montaż poręczy również od strony wewnętrznej. Poręcze wewnętrzne w znacznym stopniu utrudniają montaż elementów elewacji szczególnie w przypadku paneli szklanych. Alternatywą dla poręczy wewnętrznych są poszerzenia w postaci konsol lub stosowanie środków ochrony indywidualnej. Poszerzenia umożliwiają uzyskanie odstępu poniżej $20 \mathrm{~cm}$ co eliminuje konieczność stosowania poręczy. Ponadto mogą być w łatwy sposób demontowane po wykonaniu prac i przenoszone na kolejny obszar.

\subsection{Przeglądy rusztowań}

Należy pamiętać, iż przed rozpoczęciem użytkowania rusztowania należy dokonać odbioru przez kierownika budowy lub osobę uprawnioną, w domyśle inną osobę posiadającą uprawnienia do pełnienia samodzielnych funkcji w budownictwie. Odbiór rusztowania dokonuje się wpisem do dziennika budowy lub w protokole odbioru technicznego. W protokole należy jednoznacznie wskazać takie elementy jak: dopuszczalne obciążenia pomostów, przeznaczenie rusztowania, możliwość montażu siatki ochronnej, użytkownika rusztowania, wykonawcę montażu, datę przekazania rusztowania do użytkowania, oporność uziomu oraz terminy kolejnych przeglądów rusztowania. Podczas prac wykonywanych na rusztowaniu należy przestrzegać ogólnych zasad BHP i zasad BHP przy pracach prowadzonych na wysokości i na rusztowaniach. Kontrola rusztowań w trakcie ich użytkowania jest obowiązkowa. Należy prowadzić codzienne przeglądy przez pracownika firmy eksploatującej rusztowanie szczególnie w zakresie zakotwień, uszkodzeń zaczepów pomostów i ich powierzchni. Podczas przeglądów warto też zwrócić uwagę na kompletność rusztowania oraz ewentualne poluzowanie połączeń lub kotwień. Przegląd rusztowania należy także wykonywać po wystąpieniu niekorzystnych warunków atmosferycznych typu burza, silne wiatry powyżej $10 \mathrm{~m} / \mathrm{s}$ oraz w przypadku upadku na rusztowanie ciężkich urządzeń lub materiałów. Najgorszą sytuacją jest zezwolenie na wykonywanie pracy bez poprzedniego przeprowadzenia przeglądu. Osoby użytkujące rusztowanie musza mieć pewność, że nic nie zagraża ich bezpieczeństwu, ponieważ tylko wtedy mogą się skupić na wykonywanej pracy. Przegląd rusztowania jest najtańszym sposobem zadbania o bezpieczeństwo jego użytkowników.

\section{Podsumowanie}

W artykule zostały wskazane newralgiczne elementy konstrukcji rusztowania, na które należy zwrócić szczególną uwagę zarówno w trakcie użytkowania jak i montażu. Sam przepis nie zapewni bezpieczeństwa. Tylko właściwa interpretacja i wprowadzenie zapisów aktów prawnych w życie zapewnia bezpieczeństwo użytkownikom. Oczywiście, stosując się do przepisów, należy zachować zdrowy rozsadek, nie każdą sytuacje przewidują przepisy prawa. Skomplikowane obiekty wymagają wzajemnej współpracy pomiędzy trzema podmiotami: projektantem, montażystami i użytkownikiem. Tylko w takim przypadku zostaną spełnione trzy podstawowe funkcje rusztowania: zapewnienie nośności i bezpieczeństwa, możliwość realizacji inwestycji i komfort użytkowania. Żadna $\mathrm{z}$ tych funkcji nie może być pomijana i każda z nich jest tak samo ważna. Należy uświadamiać potencjalnych użytkowników o grożącym niebezpieczeństwie przed wystąpienie sytuacji niebezpiecznej. W praktyce dopiero, gdy dojdzie do wypadku osoby zdają sobie sprawę jak niebezpieczne jest użytkowanie rusztowań niekompletnych lub nie spełniających odpowiednich certyfikatów. 


\title{
Literatura
}

1. Rozporządzenie Ministra Infrastruktury z dnia 6 lutego 2003r. w sprawie bezpieczeństwa i higieny pracy podczas wykonywania robót budowlanych (Dz. U. z 2003r. nr 47, poz. 401).

2. Rozporządzenie Ministra Pracy i Polityki Socjalnej z dnia 26 września 1997 r. w sprawie ogólnych przepisów bezpieczeństwa i higieny pracy (tekst jedn.: Dz. U. z 2003 r. Nr 169, poz. 1650 z późn. $\mathrm{zm}$.).

3. Rozporządzenie Ministra Gospodarki z dnia 20 września 2001 r. w sprawie bezpieczeństwa i higieny pracy podczas eksploatacji maszyn i innych urządzeń technicznych do robót ziemnych, budowlanych i drogowych (Dz. U. Nr 118, poz. 1263).

4. Rozporządzenie Ministra Infrastruktury z dnia 23 czerwca 2003 r. w sprawie informacji dotyczącej bezpieczeństwa i ochrony zdrowia oraz planu bezpieczeństwa i ochrony zdrowia (Dz. U. Nr 120, poz. 1126).

5. Rozporządzenie Ministra Infrastruktury i Rozwoju z dnia 11 września 2014 r. w sprawie samodzielnych funkcji technicznych w budownictwie (Dz. U. 2014 poz. 1278).

6. PN-M-47900-2:1996 Rusztowania stojace metalowe robocze - Rusztowania stojakowe z rur.

7. Kmiecik P., Gnot D. Budownictwo. Bezpieczne rusztowania. Państwowa Inspekcja Pracy, Główny Inspektorat Pracy, Warszawa 2014r.

8. PN-EN 12811-1:2007 Tymczasowe konstrukcje stosowne na placu udowy - Część 1:RusztowaniaWarunki wykonania i ogólne zasady projektowania.

9. $\quad$ Pieńko M., Błazik-Borowa E. Wykorzystanie rusztowań budowlanych do prac na wysokości podczas remontów obiektów przemysłowych. Materiały Budowlane 10 (2012) 58-60.

10. Kałuziński D., Mańko Z. Uszkodzenia rusztowań w czasie budowy nowych wiaduktów nad autostrada A18. XXIII Konferencja Naukowo-Techniczna Awarie Budowlane, Szczecin 2007, s. 895-902.

11. Flaga K. Refleksje na temat katastrofy budowlanej przy budowie wiaduktu drogowego w Ogrodzonej, XXII KNT Awarie budowlane, 2005, s. 53-66.

\section{Scaffolding - regulations and practice}

\section{Michal Pieńko, Aleksander Robak, Ewa Błazik-Borowa}

\begin{abstract}
Department of Structural Mechanics, Faculty of Civil Engineering and Architecture, Lublin University of Technology,e-mail:m.pienko@pollub.pl,a.robak@pollub.pl, e.blazik@pollub.pl
\end{abstract}

\begin{abstract}
The paper deals with the practice versus scaffolding regulations. Due to a short period of scaffolding use, the quality of its performance is neglected. Legal acts of the scaffolding, are not always clear, which causes many problems. Minor changes to the static scheme, resulting from the need to adapt the scaffolding to irregular shapes of the object, can significantly reduce the load capacity of the scaffolding structure. Individual approach and direct cooperation are necessary of both fitters and designers during the assembly stage. Since the scaffolding used as temporary roofing for performing finishing work during the winter are not included in the catalogues and each time it is necessary to develop a separate document. Scaffolding is set directly at existing or constructed facilities and require to take all the infrastructure around it into account. It is also necessary to trace the technological process of work in order to eliminate possible overlapping of mutually exclusive processes.
\end{abstract}

Keywords: scaffolding, legal acts, health and safety regulations, safety. 